\title{
THE TRANSFORMATIONS OF SLOPE SLIDE LANDSCAPES OF GREAT CAUCASUS: POSSIBILITIES OF DISCOVERING OF MAIN FACTORS
}

\author{
1Ilham MARDANOV, ${ }^{2}$ Mirnuh ISMAYILOV, ${ }^{3}$ Elina KARIMOVA, ${ }^{4}$ Stara TARIKHAZER \\ ${ }^{1}$ Sumgait State University, SUMGAIT, AZERBAIJAN REPULIC \\ 2,3.4 Institut of Geography named by acad. H.A. Aliyev of ANAS, Baku, AZERBAIJAN REPULIC \\ 1geography.sumqayit@mail.ru, 2azgeo@yandex.ru, 3bakinskiy.breeze@gmail.com, \\ ${ }^{4}$ kerimov17@gmail.com
}

(Geliş/Received: 08.11.2018; Kabul/Accepted in Revised Form: 06.12.2018)

\begin{abstract}
In this study, the criteria that need to be considered for the selection of an appropriate wind turbine brand were settled based on a predetermined location of wind turbine. A hierarchical structure was established and Analytical Hierarchical Process (AHP) method was applied on the decision of selection for the best wind turbine among candidate turbine brands by means of this structure. Results obtained by this way were evaluated and the turbine which is selected among alternative turbine brands was investigated in detail.
\end{abstract}

Key Words: Caucasus, Erosion, Exodynamic, Factor, Landscapes, Processes, Slope, Sub district,

\section{Büyük Kafkas Dağlarının Toprak Kayması Yapısının İncelenemsi: Temel Nedenlerin Belirlenmesi}

ÖZ: Büyük Kafkasya'nın Azerbaycan sınırına giren Güneydoğu ucu, ekzojenik kabartı oluşma süreçlerinin yüksek dinamizmi ile karakterize edilir ve bu da bir manzaranın oluşmasında önemli rol oynar. Buna rağmen, ölümcül risk taşıyan çeşitli tepelerde, bir coğrafi ekolojik durumun olası değişiklik senaryolarının inşası için neden ve etki ilişkilerinin ortaya çıkarılmasıyla çeşitli yöntemlerle çalışma zorunluluğu vardır. Bu bakış açısıyla, bu çalışmalarda, Büyük Kafkasya'nın doğal alanlarındaki heyelanların tahmin edilmesine yönelik çeşitli kullanım olanakları ve görsel gözetim olanakları incelenmiştir.

Anahtar Kelimeler: Kafkasya, Erozyon, Eksojenik, Faktör, Manzara, Proses, Eğim, Alt bölge

\section{INTRODUCTION}

Questions of revealing of the reasons of geodynamic processes - taluses, scatterings and landslips are many years in the center of attention of the geographical public of the country because of fatal consequences of these phenomena for social sphere and economic activities of all mountain regions (Makarov et al., 2003; Alizadeh et al., 2005; Pashayev, 2007; John F. Shroder JR, 2010; Christine et al., 2008; Bell et al. 2012; Ji-Hyung et al., 2013).

Southern and Northern slopes of the Great Caucasus differ the difficult geomorphologic structure, shown in difficult structure of alternation of water-permeable layers of breeds, an interlacing of tectonic infringements, and also the high seismicity which often enough is hardly noticeable, but a determinative of slipping and a collapse of weights of breeds (Figure 1.). 


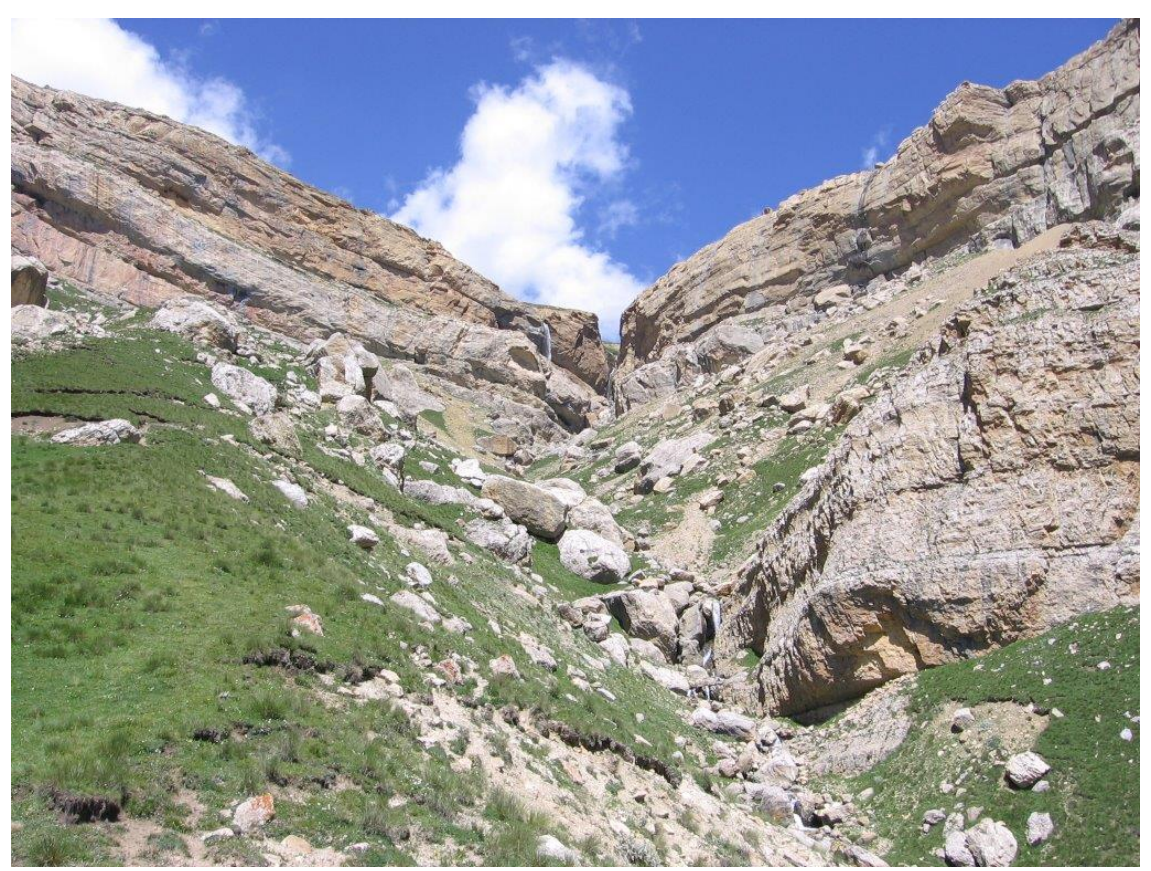

Figure 1. The rocks of Shahdag massive which may be the material of mood flow streams.

Essential influence on development slope slide processes renders the inclination of a terrestrial surface saving in considerable energy of all weight of breeds of a slope. But, as it is known, the big biases of slopes not always lead to landslips, even on close located to slope slide files sites. So, slopes with firm parent breeds are steady, slopes with alternation of layers of friable breeds and clays are the most subject to influence of geodynamic factors. The big biases of slopes, especially characteristic for the Southern slope of the Main Caucasian ridge lead to landslips of landslide character, in a root changing shape of a landscape of the given site (Mardanov and Hajizadeh, 2003; Budagov et al., 2005, Mardanov et al., 2005).

On degree of stability to influence slope slides processes of territory of hills are differentiated on rather steady, middle active and active sites. Within a mountain-meadow zone steady in slope slide relation sites are characterized by presence of clearly expressed subalpine and Alpine landscapes. Such sites can be subject to influence of others exodynamic processes - to soil erosion, accumulation and moving of taluses and the scatterings representing not smaller danger to a landscape and all ecological situation.

As it is known, an important element of development of landscapes is carrying over of chemical particles as a part of circulation of substances. In this respect high-mountainous landscapes of the Great Caucasus are not much studied and demand the influence analysis exogenic processes on changes of quantity and a parity of various chemical elements and their connections in soils and vegetation depending on intensity of the various natural phenomena. For these purposes experts of a various profile - geographers, soil scientists, botanists, the chemists which general efforts can help to reveal an overall picture of occurring geochemical changes can be involved.

The geodynamic situation in Apsheron substantially becomes complicated the intensive townplanning accompanied by development of a social and industrial infrastructure that leads to change of an initial relief and strengthening of factors of slope slide forming.

\section{OBJECTS AND METHODS OF RESEARCHES}

The Southeast extremity of the Great Caucasus which are active from the point of view of a descent of landslips, always drew attention of researchers of various disciplines - geologists, geomorphology scientists, landscape scientists, soil scientists etc. trying to establish the reasons of this destructive 
process, to state an estimation of degree of influence of this or that factor on the given phenomenon. The basic landscape elements of separate large landslips have been in this time defined main slope slide files, lithologic structure of breeds of slope slide slopes (Alizadeh et al., 2015).

These works were made during field visual researches, and also the cameralistic researches meaning measurements on topographic maps, revealing the biases of a surface stimulating slipping of mountain weights.

Gaugings of the cracks formed as a result of landslips on different files and definitions of their time dynamics allow spending in certain degree territory division into districts on activity of breeds for the purpose of revealing most of slope slide dangerous territories (Guliyeva et al., 2014; Alizadeh et al., 2015). The description of a landscape situation, its separate components promotes revealing of the distinctions shown through certain time occurring also under the influence of geodynamic processes.

High-mountainous areas of the Greater Caucasus, including the mountain meadow zone, are characterized by a complex combination of natural and anthropogenic factors, leading to the development of a complex landscape structure. These factors complicate the morphological structure of the entire mountain meadow strip, forming various tracts and facies, the main causes, the formation of which are geodynamic processes. It is these processes that cause a different degree of fragmentation of the surface, and as a natural consequence, to landscape diversity.

The fragmentation of the surface, caused by soil erosion, is manifested in the presence of sites of different degrees of erosion of different types of mountain meadow soils. Such areas can be considered as the most common landscape tracts in the mountain-meadow zone.

Typologically, subalpine and alpine meadows are distinguished as independent subzones, the boundaries of which are certain hypsometric heights. As a subzone, it is possible to identify post-forest meadows that occupy significant areas from 1500 to $1600 \mathrm{~m}$ in the basins of the Girdimanchai, Ahsu and Pirsaat rivers. Hayfields, being, as a matter of fact, widespread tracts, can be considered as the most widespread in this zone of anthropogenic complexes.

Within this zone facies can be identified by individual geobotanical groupings forming facies groups, since these facies can be formed at different altitudes, on slopes of different exposures and different surface slopes.

As facies can be considered areas with different groups of meadow and shrubby plants that form on certain types of mountain meadow soils. Separate facies are temporary lakes, the cause of which is the accumulation of the blocks of rocks wedged out as a result of displacement to the surface of groundwater and precipitation water. Changes in the configurations of their shores and locations, their drainage, indicates a landslide activity and can be taken as an indication feature when assessing the dynamics of geodynamic processes.

Independent landslide tracts are landslide massifs occupying large areas within which various mountain meadow soils and plant groups are observed. Landslide areas, which sometimes have a great length, can cut through several landscapes. These sites are distinguished by a certain differentiation of detrital material, which are a concomitant element of all forms of geodynamic relief.

The areas of accumulation of scree and placer material of various sizes are separate facies. Areas with different degrees of clastic material accumulation by meadow or shrubby vegetation are also landscape facies, widely widespread on landslide massifs. The number of such facies can be increased with more detailed geobotanical studies, which will allow determining the various plant groups in such areas.

Analysis of the degree of subdivision of the surface on landslide massifs makes it possible to further detail the morphological structure of the landscape, to identify areas with weak, medium and strong dissections of various plant groups. Such an analysis can make it possible to determine the most rational combinations of meadow and shrubby plants when planning phytomeliorative work on the dissected surfaces of other territories and even other landscape zones.

For the analysis of the landscape situation in the subnival-nival zone of the north-eastern slope of the Greater Caucasus, a joint analysis of topographic maps and aerial photographs was carried out, the 
installation of which made it possible to identify the largest rock-nival massifs in order to assess the geodynamic situation in the given territory.

But for these purposes it is also very important to use high-resolution satellite imagery that allows you to view in detail all the differences in the landscape situation and to associate them with the nature and intensity of exogenous relief-forming processes. Images of low resolution can be of an overview nature and can only be used to determine the existence of a particular natural process or the shape of the relief.

A vivid example of the distribution of such sites are the territories around the mountains of Shahdag $(4243 \mathrm{~m})$ and Gizilgaya $(3,726 \mathrm{~m})$, located near the intersection of the Lateral and Mykhtokyan Ridges. Shahdag, being one of the highest mountains of the entire of Azerbaijan Republic, differs from the saddle shape of the mountain, which determines the specific character of denudation of frost weathering and snow accumulation materials. These materials in the form of placers are actively transported along the south-western slopes of the Lateral Ridge towards the river Gusarchay and its tributary Shakhnabad, but the leveling of the riverine territory, the presence of a stable soil cover reduces the dynamics of denudation, creating a calmer landscape situation.

Brightly manifested tracts around the mountain are steep slopes massive, with a strong degree of dissection, sharply separating it from the surrounding highland territory. The saddle vertex allows active snow accumulation, transforming into ice formation. Unfortunately, the available aerial and space images do not allow us to determine the boundaries of the glacier, but they make it possible to fairly confidently decipher the areas of snow cover distribution, areas with varying degrees and the nature of snow accumulation. This makes it possible to isolate the snow subzone within the subnival-nival zone, forming within this massif, with a large number of peaks of altitude of 3,500-4,000 meters, an especially wide band.

The north-western extension of Shahdag is the Yarydag massif $(4116 \mathrm{~m})$, which is a highmountainous massif that descends gradually in the form of rock ledges to the valley of the river Chekhychay, flowing through the territory of Dagestan in the north-northeast direction. Almost flat areas are located to the west of the mountain Yarydag, and these parts, as well as the Yarydag tract stretching to the south from the top from the south-west to the northeast, are characterized by active snow accumulation, brightly reflected in aerial photographs. Rock cliffs to the north-west of the summit form several steps, forming a complex alternation of processes of frost weathering, denudation and accumulation. In the rest of the study area, high rock cliffs with a strongly dissected surface are characterized by poor snow accumulation, like the slopes of the Shahdag and Gizilgaya massifs, but less accumulation of loamy material at their foot. This can be explained by his intensive transfer to the foot of the massif in the riverbeds of Shakhnabad, Chutorvac and Chekhychay.

In a geodynamically no less interesting landscape situation is the subnival-nival zone around the peaks of the Gyzylgaya massif, located to the southeast of Shahdag, also having a saddle shape. Despite the significantly smaller absolute height in comparison with Shahdag, the surface of the Gizilgaya massif has no less a wide band of snowfields covering the mountain. The southern slopes of the massif, like Shahdag, form a wide strip of highly disjointed, almost vertical slopes. The weathering materials of these slopes actively accumulate at their foothills, forming a clarified granular strip on aerial photographs, passing into placers, tearing down the slopes of the mountain meadows of the Gudialchay River basin.

Illustrative of the evidence of the impact of climate severity on the development of rocky landscapes covered with extensive snowfields are the highland massifs of the Khinalig and Suttutpe peaks located on the Gaitar-Goja ridge stretching parallel to the Main Watershed and Lateral Ranges.

Despite the relatively lower absolute altitude in comparison with such peaks as Bazarduzi, Tufandag and Shahdag, on Khinalig, characterized by the presence of clearly expressed glacial relief forms, snowy areas with outcrops of rocky and detrital rocks occupy long strips. Apparently, the reason for the predominance of such areas over solid snowfields is the steepness of this part of the northeastern slope of the Greater Caucasus and, in particular, of the Gaytar-Goja Range in comparison with the 
Lateral Range. Such steepness apparently causes the displacement of snow masses down the slopes and drainage of thawed waters during thawing of snowfields during the warmest periods.

There is a possibility that it is the thawed waters of these massifs in the period of intensive thawing that are responsible for the removal of loose fragments of talus widespread on the southern slopes into the channel of the Gudialchay River flowing through several landscape zones, increasing the mud flow hazard in this fragment of the highland belt of the northeastern slope of the Greater Caucasus. Although this territory is not distinguished by the presence of a large number of settlements and the danger of the impact of exodynamic processes on people's homes is relatively limited, but the situation can drastically change with the continued active involvement of this territory, located in close proximity to the village of Khinalig, which has ethnographic value in tourism activities in a park mode. For this reason, there is a need to include this territory in a number of priority areas in order to implement priority preventive measures to protect the population and tourists from natural disasters.

The interpretation of space images gives the chance to their interpretation for revealing of geomorphologic and landscape features of consequences of landslips both their spatial and time dynamics in the presence of pictures of different years. In Azerbaijan many years were spent works on creation and perfection of various means and methods of interpretation of the space data for definition of directions of development of the fatal natural phenomena (Mekhtiyev, 1998).

\section{THE RESULTS}

Materials of numerous researches of an environment of the Great Caucasus available in presence can give the chance to reveal occurrence and development preconditions slope slide processes and to create certain grouping of slope slide files for the purpose of working out of protective actions for prevention of their fatal consequences. The material on physical-geographical and synoptic division into districts of natural area of the Great Caucasus within Azerbaijan has been with that end in view processed and a number of the factors causing a descent of slope slide of weights are defined. So, around the Garauzchay landslip slope slide processes occur in conditions concerning a droughty climate and consequently the role of climatic factors in the given area is insignificant (Figure 2 and 3.). The landslip has a complex surface relief on the steeply sloping terrain, which can be explained by the nature of the alternation of rocks, different resistance to geodynamic energy, and high seismicity characteristic of a given area (Figure 4 and 5).

1. Fresh slope slide materials, rare bushes on steep, abrupt, strong dismembered cracks and ravines amphitheatre slopes.

2. Fresh slope slide materials on steep, abrupt, strong dismembered cracks and ravines amphitheatre slopes.

3. Fresh slope slide materials, rare bushes on weak inclined, weak dismembered cracks slopes of a cone of carrying out and a transitive site.

Rare bushes, pools on weak inclined, strong dismembered cracks and ravines slopes. 


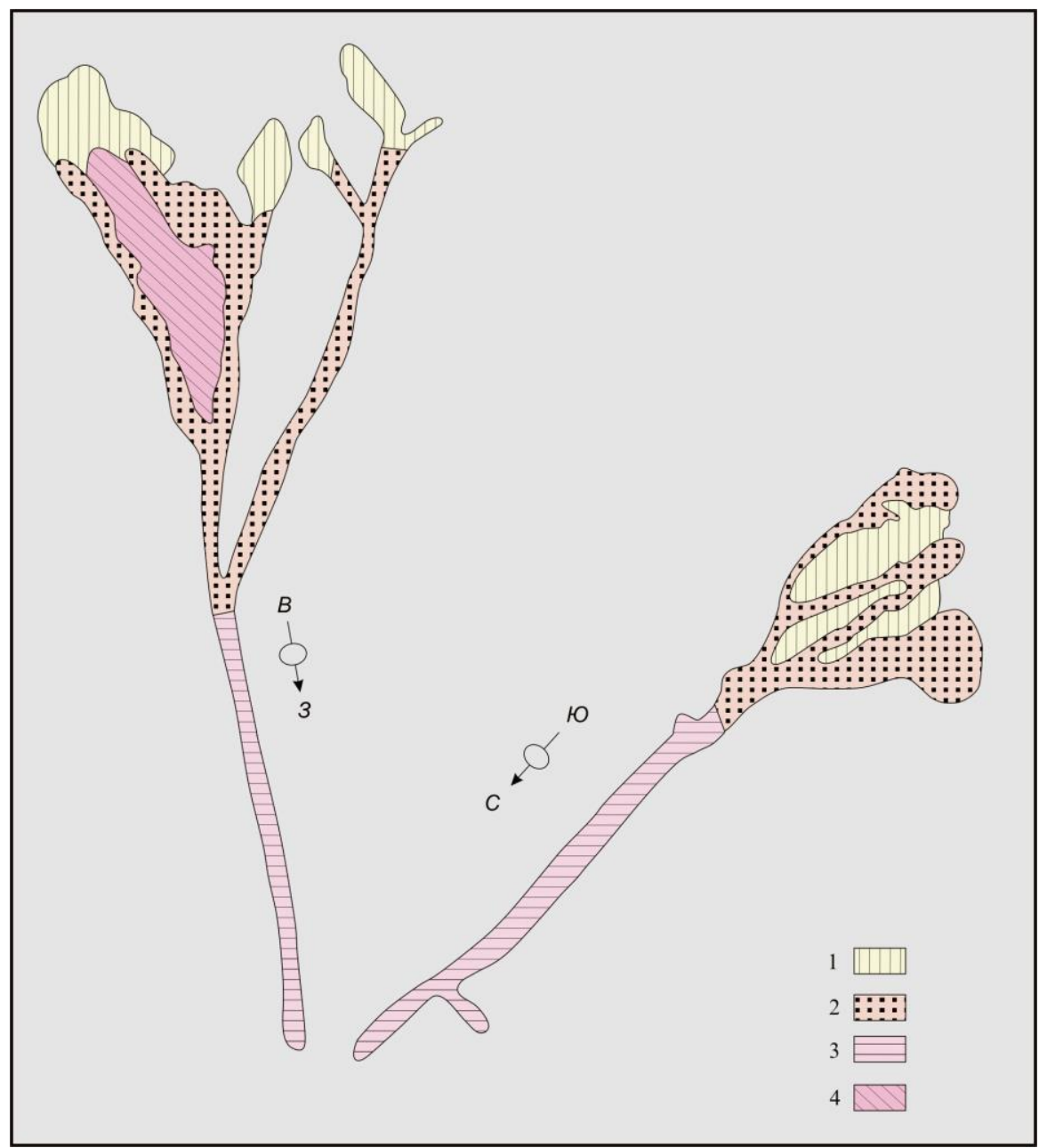

Figure 2. The Garauzchay landslip-stream ( $40^{\circ} 52^{\prime}$ north latitude, $48^{\circ} 27^{\prime}$ eastern altitude)

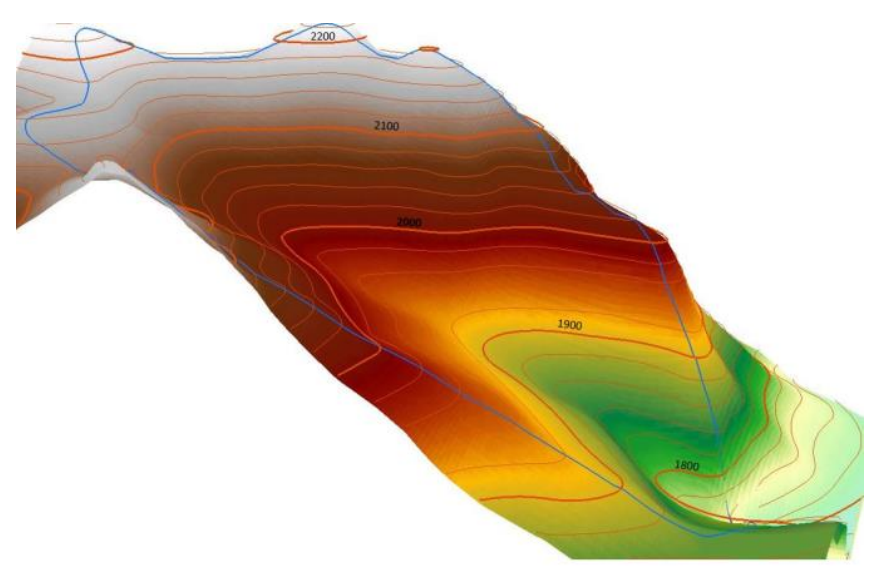

E-W

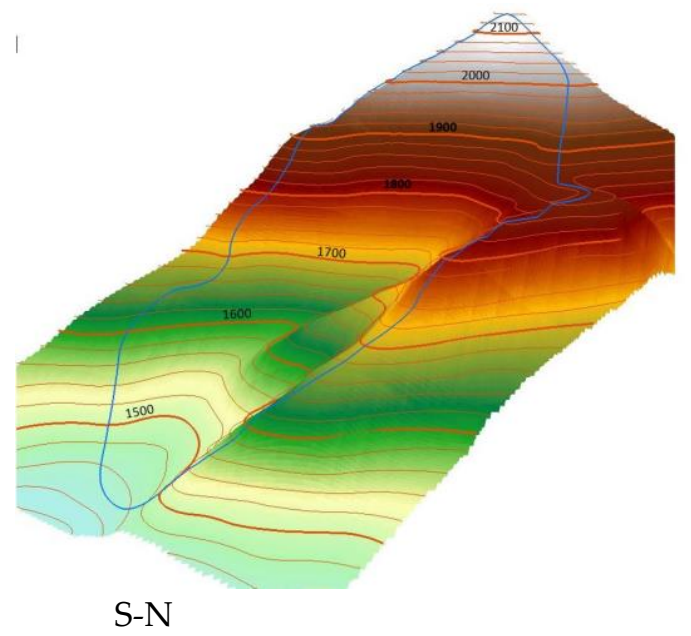

S-N

Figure 3. The digital model of Garauzchay landslip-stream, situated in mountain-meadow and mountain-forest zone. It has got different relief of cover 


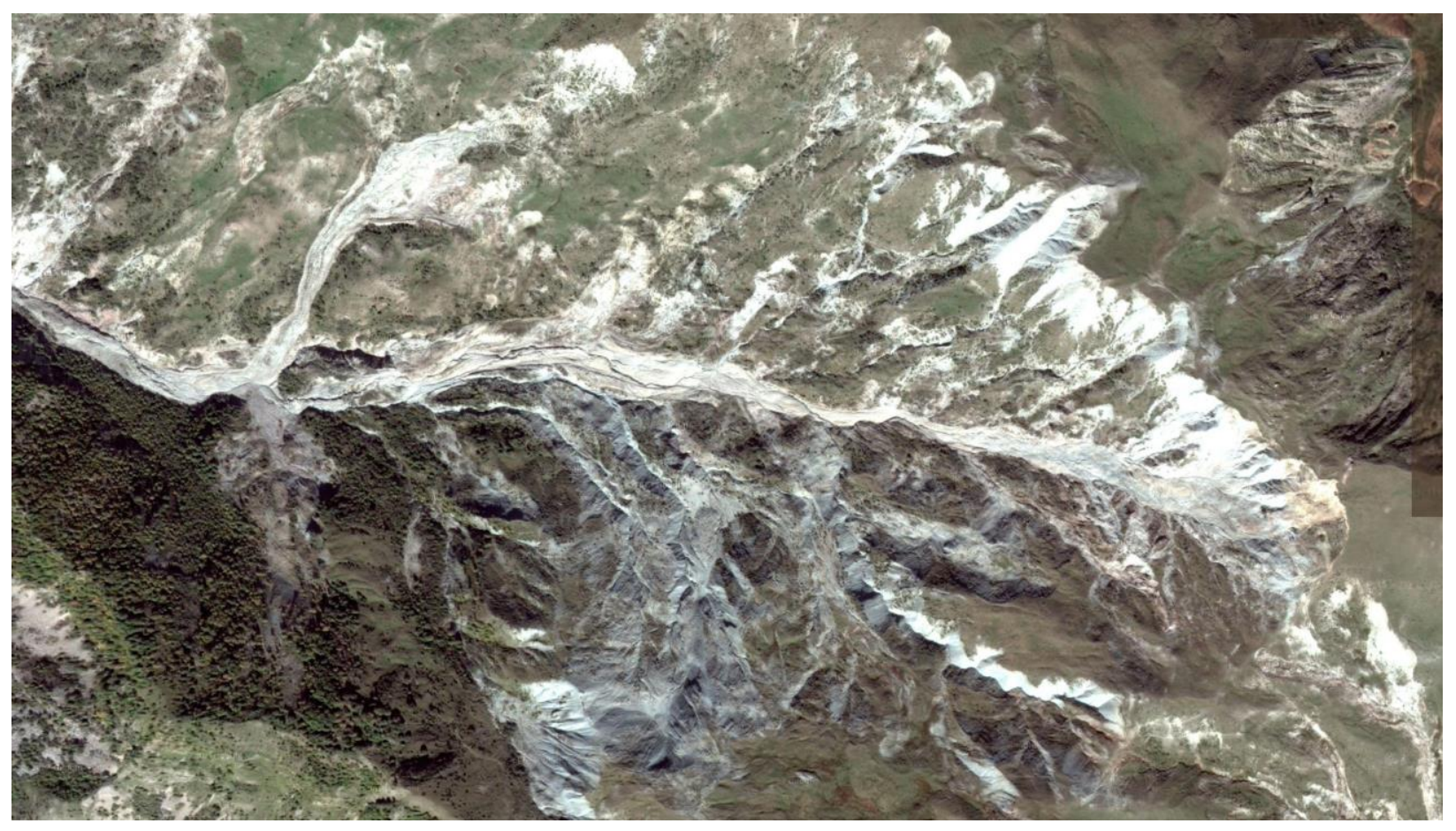

Figure 4. The sleeve of the Garauzchay landslip-stream, which has an east-west strike 


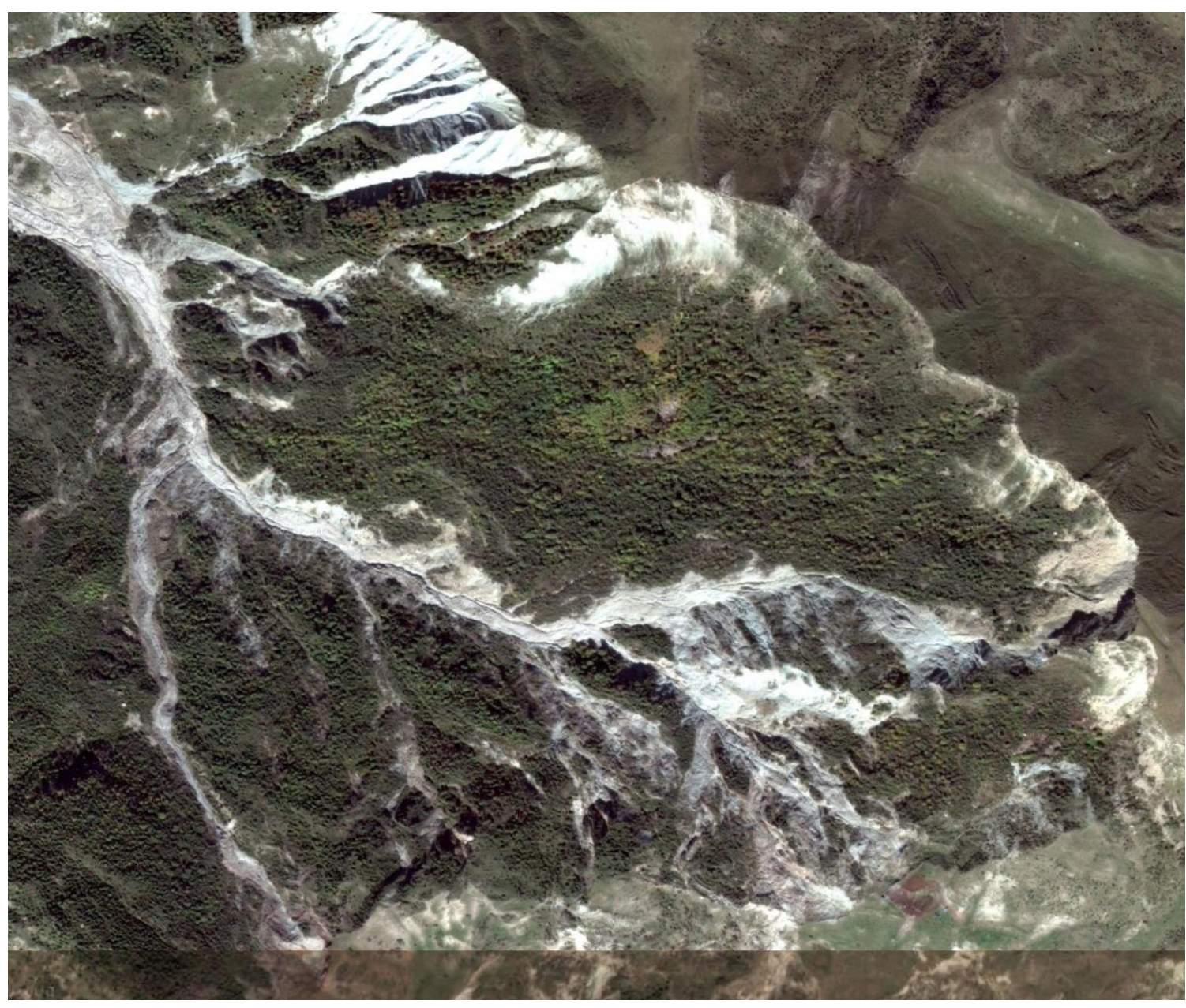

Figure 5. The sleeve of the Garauzchay landslip-stream, having a south-north strike and capturing all new areas, reflected by a light phototone separating them from the adjacent mountain forest and mountain meadow landscapes (a photo of the company "Google" (USA), with a resolution of $1 \mathrm{~m}$, filmed September 29, 2012-th year)

\section{Ekonomik Özellikler (Economical Properties)}

High-mountainous territories of the Great Caucasus are included into limits of several physicalgeographical areas. The Gonagkend area covers in the structural relation Tufan anticlinorium, ShahdagHyzi synclinorium, Tengi-Beshbarmag anticlinorium, east suburb Zagatal-Govdag synclinorium and Hussar monoclinal. In connection with formation at various absolute heights of some intermountain hollows conditions for development of settlements, agriculture and cattle breeding which however, can serve as the reason erosive, but not slope slide process are created. The slope slide phenomena here have the natural character connected, apparently, with fluctuations of seismic activity, character of the spreading breeds, washing away activity of the rivers, especially, during high waters and an atmospheric precipitation, including, storm rains. The intermountain hollow of Shahdjuzju (2400-2700 meters) is used as a summer pasture. The area relief possesses the big range of heights (200-4460 meters) and consequently high-rise zone forming is presented here in a full spectrum. In connection with fall in a southeast direction of absolute height of a relief and strengthening aridity in hillsides reduction of a river drain and disappearance of high-mountainous landscape belts, aridity forming of woods, expansion of areas of dry steppes and semi-deserts aside low-mountain relief is observed. In dynamic development and formation of a relief a dominant role play gravitational (collapses, landslips) and erosive processes, but a bycicle a role and exaration activity of the rests of an ancient freezing. 
Differences of heights on the Southern slope of the Main Caucasian ridge which basically, covers the Zagatal-Lahich physical-geographical area stretched from the West, from the Georgian border to a river of Girdimanchay valley in the east on 220 kilometers, with abrupt slopes are made by 2800-2900 meters. Surface biases change in limits $30^{\circ}-45^{\circ}$ that probably is the leading factor of development of slope slide processes, along with showers, characteristic and for the Northern slope of the Great Caucasus and high seismicity. A number of the rivers (Mazymchay, Belokanchay, Kurmuhchay, Dashagilchay, etc.) cross the Southern slope across, forming valleys with abrupt slopes. In territory dominate of broad-leaved forests which however can't serve fixing from sliding of breed by the factor, mountain meadows and sub nival landscapes. In connection with the big area of the bared slopes covered with materials of aeration, the rocky exposures, periodically dropping out storm rains in pools of the rivers form have sat down, which work great mischief to the population and economy of foothill areas. The landslips, which occurrence also it is not connected in the direct relation with the anthropogenic factor, are most widely developed on the average a watercourse of Girdimanchay, in the Lahich hollow on slopes of mountains and create obstacles to economy development, settlements.

The Shemahi (Mountain Shirvan) physical-geographical area surrounded from the West the river Ahsu, from the north a watershed of the Main Caucasian ridge, from the east with Gobustan lowmountains, and from the south Shirvan steppe is characterized by high seismicity (8-9 points) which probably plays the leading part in coupling infringement between weights of breeds and a descent of landslips. In area territory where unlike previous, with more damp climate, mountain-steppe, foreststeppe, mountain-wood and mountain-meadow landscape complexes prevail. Here consequences of landslips in connection with low-populated territory, fortunately, didn't lead to the big human victims, but periodically put out of action the main road on which fluid repair the considerable quantity of public funds leaves. Landslips in pools of the rivers Ahsu, Pirsaat and Gozluchay which work great mischief to settlements, roads and economy are most widely developed. The site of Chuhuryurd-Pirgulu is convenient as a zone of rest and possesses features of the mountain-climatic resort which expansion can will aggravate a problem of its protection against natural accidents.

\section{CONCLUSIONS}

The numerous researches directed on working out of actions for prevention of a descent of landslips are based on the purposes of reduction of biases of hillsides, the phytomeliorative works meaning restoration of a close vegetative cover on broken files. Such approach starts with insufficient understanding of an essence of the mechanism of the given process covering not simply terrestrial surface, but powerful enough cover of sedimentary breeds with certain stratification, sometimes some tens meters. Often enough in publications of various character there is an expression "sliding of soils," that starts with misunderstanding of a geological-geomorphologic essence of slope slide process, the superficial relation to possible consequences of this phenomenon. Cases of the big human victims as a result of landslips, for example, tragedy of the settlement Varna located on the Southeast slope of the Main Caucasian ridge, carried away lives of many inhabitants of village are known. Geologists mark presence of earthquakes of slope slide character, being an element of a geodynamic chain.

At the same time, land improvement attempts of slope slide files which are ineffective are undertaken. They, basically, are directed on alignment of a surface and restoration of a close soilvegetative cover, including, by realization of forest melioration.

The given measures lead to time stabilization of a geodynamic situation that actually, is the beginning of a new cycle in development of slope slide process. Planting of trees improves soilecological, but not geological-geomorphologic situations as roots of trees aren't capable to constrain movement of weights of breeds sufficiently. As an example numerous landslips within a mountainwood belt of the Great Caucasus within Azerbaijan, strongly changed all shape of a landscape can serve, introducing before not meeting elements in its horizontal structure. 


\section{PROSPECTIVE ACTIONS}

Thereupon there is a severe need in large-scale inventory of slope slide files, meaning drawing up detailed landscape, geological-geomorphological, soil and geobotanical sketch maps, including, with use of materials of space shooting (Pike, 2000; Shary et al., 2002; Thompson et al., 2001; Li et al., 2005; Taud and Parrot, 2005; Etzelmuller et al., 2007; Zhou et al., 2008; Bell et al., 2012; Mehbaliyev et al., 2016). Maps and sharts should be added by the meteorological data including the information on an annual course of temperature of air, quantity, character and a mode of loss of deposits, mid-annual and monthly average temperatures of air.

In the description of slope slide file the information on a humanitarian and economic situation of slope slide site, including the data about quantity of settlements, number of their population, type of settlement, features of their arrangement, quantity and character of the enterprises, the social objects located in given territory should occupy an important place (Mardanov and Aliyev, 2016).

Accumulation and processing of great volume of the data presumes to spend comparison of the probable factors causing process of a descent of landslips and to reveal the key factor which has been not considered by initial consideration, for the purpose of search of possibilities of its neutralization (Mardanov, 2009; Garibov et al., 2016; Alizadeh et al., 2016).

\section{REFERENCES}

Alizadeh, E.K., Guliyeva, S.Y., Kuchinskaya, I.Y., Tarikhazer, S.A., 2015, "Intensity of Landslips in Mountain Geosystems of Azerbaijan and Its Estimation", International Journal of Scientific Research and Innovative Technology, ISSN 2313-3759. Vol 2, No.10.

Alizadeh, E.K., Guliyeva, S.Y., Tarikhazer, S.A., 2005, "The Assesment of Degree of Susceptibility of Geocomplexes of the Southern slope of Greater Caucasus Landslide Processes", Scientific and practical conference "Natural and Destructive Phenomena of Sheki-Zakatala Area and Ecogeographical Problems of Development of the Region", Sheki, pp. 63-65, 9-10 June 2005.

Alizadeh, E.K., Ismayilov, M.J., Guliyeva, S.Y., Zeynalova, S.M., Tarikhazer, S.A., Yunusov, M.Y., Mustafayev, N., Mammadbayov, E.Sh., 2016, "The Assessment of Landscape and Environmental Risks and Hazards Caused by Landslides in Mountain Areas", Applied Ecology and Environmental Research, Vol. 14(3), ALÖKI Kft., Budapest, Hungary, pp. 573-586.

Bell, R., Petschko, H., Röhrs, M., Dix, A., 2012, "Assessment of Landslide Age, Landslide Persistence and Human Impact Using Airborne Laser Scanning Digital Terrain Models", Geografiska Annaler: Series A, Physical Geography Special Issue: Thematic Issue: Concepts and Implications of Environmental Change and Human Impact: Studies from Austrian Geomorphological Research, March, Vol. 94, Issue 1, pp. 135-156.

Budagov, B.A., Alizadeh, E.K., Tarikhazer, S.A., 2005, "Current Trends of Development it is Spontaneous - Destructive Processes and an Assessment of Ecogeomorphological Danger (on the example of the southern slope of Greater Caucasus)", the Scientific and Practical Conference "Natural and Destructive Phenomena of Sheki-Zakatala Area and Ecogeographical Problems of Development of the Region", Sheki, pp. 25-28, 9-10 June 2005.

Christine, A., Katrin, M., Monika, B., Dominik, B., 2008, "Methods to Describe and Predict Soil Erosion in Mountain Regions", Landscape and Urban Planning, Vol. 88, H.2-4, pp. 46-53.

Etzelmuller, B., Romstad, B., Fjellanger, J., 2007, "Automatic Regional Classification of Topography in Norway", Norwegian Journal of Geology, Vol. 87, pp. 167-180.

Garibov, Y., Mardanov, I., Ismaylova, N., Ahmadova, G., Aliyeva, R., 2016, "Exogenetic Features Landscapes of High Mountains of the Greater Caucasus with in Azerbaijan Republic", British Journal of Educational and Scientific Studies, Source Normalized Impact per Paper (SNIP): 5.796, SCImago Journal Rank (SJR): 5.925, No.1. (23), January-June, Vol. XII, pp. 579-585. 
Guliyeva, S.Y., Tarihazer, S.A., Kuchinskaya, I.Y., 2014, "Geodynamic Aspects of the Formation of Landslide Landscapes in the North-Eastern Part of the Greater Caucasus (within Azerbaijan)", Materials of the Geomorphologic Congress. Volgograd, pp. 80-86.

Ji-Hyung, P., Katrin, M., Inyoung, J., Hojeong, K., Christine, A., 2013, "Erosion-induced Changes in Soil Biogeochemical and Microbiological Properties in Swiss Alpine Grassland", Soil Biology and Biogeochemistry, Vol. 69, pp. 382-392.

John F. Shroder JR, Brandon J. Weihs., 2010, "Geomorphology of the Lake Shewa Landslide Dam, Badakhshan, Afghanistan, using Remote Sensing Data", Geografiska Annaler: Series A, Physical Geography, Vol. 92, Issue 4, December, pp. 469-483.

Li, Z., Zhu, Q., Gold, C., 2005, Digital Terrain Modeling: Principles and Methodology, Boca Raton London New York Washington, D.C. CRC PRESS, $318 \mathrm{p}$.

Makarov, M.I., Glaser, B., Zech, W., Malyshev,a T.I., Bulatnikova, I.V., Volkov, A.V., 2003," Nitrogen Dynamics in Alpine Ecosystems of the Northern Caucasus", Plant and Soil, October, Vol. 256, Issue 2, pp. 389.

Mardanov, I.I. 2009, "About Possibilities of Use of Expert System for Forecasting of Landslides", Proceedings of Geographical society of Azerbaijan, Vol. XIV, Baku, pp. 36-40.

Mardanov, I.I., Aliyev, E.A., 2016, "Influence of the Geodynamic Situation on Ecotourism Development in Highlands of Azerbaijan Part of Great Caucasus", TOURISM ECONOMICS, The Business and Finance of Tourism and Recreation, ISSN 1354-8166 (print); 2044-0375 (online) Impact Factor: 0.515. 5-Year Impact Factor: 0.745. Vol. 22, №1.1, pp. 94-100, February 2016.

Mardanov, I.I., Hajizadeh, F.M., 2003, "The Factors Influencing Landslide Processes in Apsheron", Desertification Problems in Azerbaijan. Materials of The Scientific and Practical Conference Devoted to the 75 Anniversary Since The Birth of The Acad, B A. Budagov, Baku, pp. 192-195.

Mardanov, I.I., Medzhidov, D.B., Medzhidova, V. G., Abdullaev, G.G., 2005, "The System Analysis of the Factors Characterizing Processes of an Lanslide Forming in Apsheron", ANASA News (It is devoted to day of astronautics), Physics and Technology Problems of Ways of Remote Sensing, Vol.8, No. 1 (8), pp. 85-92.

Mehbaliyev, M.M., Jarullayev, A.Sh., Mardanov, I.I., 2016, "Morphometric Study and Evaluation of Erosion Hazards of Mountain Geomorphosystem Slopes", Ciencia e Tecnica. Vitivinicola a Science and Technology Journal, ISSN: 0254-0223, Impact Factor: 0.278, 5-Year Impact Factor: 0.479, Vol. 31 (n. 2, 2016), pp. 457-467.

Mekhtiyev, A.Sh., 1998, "Space Researches in Azerbaijan", Materials of the Second Scientific and Practical Conference "Azerbaijan on a Threshold of the XXI Century", Baku, pp. 343-346.

Pashayev, N.A., 2007, "Management of Natural Disasters in the Territory of the Azerbaijan Republic", Proceedings of Geographical society of Azerbaijan. Modern geographical researches in Azerbaijan, Vol. XI, Baku, pp. 283-289.

Pike, R.J., 2000, "Geomorphometry Diversity in Quantitative Surface Analysis", Progress in Physical Geography, Vol. 24 (1), pp. 1-20.

Shary, P.A., Sharaya, L.S., Mitusov, A.V., 2002, "Fundamental Quantitative Methods of Land Surface Analysis", Geoderma, Vol. 107, № 1-2. pp. 1-32.

Taud, H., Parrot, J.F., 2005, Mesurement of DEM Roughness Using The Local Fractal Dimension, Geomorphology: relief, environment, №4, P. 327-338.

Thompson, J.A., Bell, J.C., Butler, C.A., 2001, "Digital Elevation Model Resolution: Effects on Terrain Attribute Calculation and Quantitative Soil-Landscape Modeling", Geoderma, Vol. 100, pp. 6789.

Zhou, Q., Lees, B., Tang, G., 2008, "Advances in Digital Terrain Analysis", Lecture Notes in Geoinformation and Cartography Series, Springer, pp. 462. 